\section{Antiproliferative Butyrolactones from Mezilaurus crassiramea}

\author{
Danilo Tófoli ${ }^{1}$, Laura Alves Verão Martins ${ }^{2}$, \\ Maria de Fátima Cepa Matos ${ }^{2}$, Walmir Silva Garcez ${ }^{1}$, \\ Fernanda Rodrigues Garcez ${ }^{1}$ \\ ${ }^{1}$ Instituto de Química, Universidade Federal de Mato Grosso do Sul, \\ Campo Grande, MS, Brazil \\ ${ }^{2}$ Centro de Ciências Biológicas e da Saúde, Universidade Federal de \\ Mato Grosso do Sul, Campo Grande, MS, Brazil
}

\section{Abstract \\ $\nabla$}

Bioassay-guided fractionation of the ethanol extract from the leaves of Mezilaurus crassiramea, which was toxic to Artemia salina larvae, afforded 3'-acetylrubrenolide (1), 2',3'-diacetylrubrenolide (2), and rubrenolide ( 3 ) from the active dichloromethane soluble fraction. Compound $\mathbf{1}$ is new, while $\mathbf{2}$ and $\mathbf{3}$ are first reported from a natural source and in the Mezilaurus genus, respectively. Compound $\mathbf{3}$ showed significant cytotoxicity against UACC-62, MCF-7, HT-29, and PC-3 human cancer cell lines, with $\mathrm{GI}_{50}$ values ranging from 3.3 to $9.9 \mu \mathrm{g} / \mathrm{mL}$, while 1 and 2 exhibited marginal activities against at least five of the six investigated cell lines. The structures of 1-3 were established on the basis of 1Dand 2D-nuclear magnetic resonance analyses, high-resolution electrospray ionization mass spectrometry data and specific optical rotation values.

Key words

Mezilaurus crassiramea $\cdot$ Lauraceae $\cdot \gamma$-lactones $\cdot$ rubrenolide cytotoxicity

Supporting information available online at http://www.thieme-connect.de/products

Mezilaurus (Lauraceae) comprises about 20 species and is distributed from Costa Rica to Southern Brazil [1,2]. Although it belongs to a widely studied plant family, the chemical composition of members from this genus has been scarcely investigated. Previous works revealed the presence of neolignans, volatile terpenoids, alkaloids, and/or a $\gamma$-lactone in Mezilaurus itauba (Meisn.) Taubert ex Mez, Mezilaurus duckei H. van der Werff, and Mezilaurus synandra (Mez) Kosterm. [3-5]. As part of our continuing research on potential anticancer constituents from lauraceous species occurring in the "Cerrado" ecosystem of Midwest Brazil, we found that the ethanol extract of the leaves of Mezilaurus crassiramea (Meisn.) Taub. ex Mez, a tree popularly known as "cumbuquinha" that has not been previously chemically investigated, showed activity in the brine shrimp (Artemia salina) lethality test $\left(\mathrm{LD}_{50}=734.8 \mu \mathrm{g} / \mathrm{mL}\right)$. After partitioning of this bioactive extract, the activity was found to rest only on the dichloromethane solubles $\left(\mathrm{LD}_{50}=29.8 \mu \mathrm{g} / \mathrm{mL}\right)$. Bioassay-directed column chromatography separations of this phase led to the isolation of the polyketide derived $\gamma$-lactones 1-3, which were evaluated for their antiproliferative effects on six human cancer cell lines (786-0, MCF-7, PC3, HT-29, UACC-62, and NCI/ADR-RES).

The high-resolution electrospray ionization mass spectrometry (HRESIMS; positive ion mode) of compound 1 suggested the molecular formula $\mathrm{C}_{19} \mathrm{H}_{32} \mathrm{O}_{5}$, as determined by the $[\mathrm{M}+\mathrm{Na}]^{+}$ion at $m / z$ 363.2141. The ${ }^{1} \mathrm{H},{ }^{13} \mathrm{C}$, and distortionless enhancement by polarization transfer (DEPT) NMR spectra of 1 ( $\bigcirc$ Table 1 ) showed resonances attributable to a long linear alkyl chain (multiplets ranging from $\delta 1.20$ to 1.61 ) bearing a terminal olefinic bond, as shown by a pair of broad doublets at $\delta 4.95(J=16.8 \mathrm{~Hz})$ and $\delta$ $4.89(J=11.2 \mathrm{~Hz})$, and a double double triplet at $5.76(J=16.8$, 11.2 , and $6.6 \mathrm{~Hz}$ ), wherein the respective vinyl carbon signals were observed at $\delta 114.1$ and $\delta 139.1$ in the ${ }^{13} \mathrm{C}$ NMR spectrum ( $\bullet$ Fig. 1). Other characteristic features in the NMR spectra of 1 accounted for the presence of an acetoxy function, as deduced from the methyl singlet at $\delta_{\mathrm{H}} 2.05$ and the carbon resonances at $\delta_{\mathrm{C}} 20.8$ and 171.1 . The signal at $\delta_{\mathrm{C}} 180.0$ was indicative of the presence of an additional ester carbonyl carbon, which showed long-range correlations in the heteronuclear multiple-bond correlation (HMBC) spectrum to the methine hydrogen at $\delta 2.82-$ $2.95(\mathrm{~m})$, and the methylene hydrogens at $\delta 1.42-1.61(\mathrm{~m})$ and $\delta$ 2.44-2.56 ( $\mathrm{m}$ ), which in turn showed connectivities in the heteronuclear single quantum coherence (HSQC) spectrum to the carbons at $\delta 38.8$ and $\delta 35.7$, respectively ( $\mathbf{F i g . 2}$ ). This data, along with a long-range heteronuclear correlation between the oxymethine carbon at $\delta 79.7$ and the methylene hydrogens at $\delta 1.63-$ 1.77 and $\delta 1.42-1.61$, the connectivities of which to the carbon resonance at $\delta 35.3$ were observed in the HSQC spectrum, as well as further information provided by the correlation spectroscopy (COSY) spectrum ( $\odot$ Fig. 2 ), indicated that a five-membered lactone moiety bearing side chains at C-2 $\left(\delta_{\mathrm{C}} 38.8\right)$ and $\mathrm{C}-4$ $\left(\delta_{\mathrm{C}} 79.7\right)$ was present in the structure of 1 . Detailed analysis of the remainder of the $1 \mathrm{D}$ - and 2D-NMR spectra revealed that 1 and rubrenolide (3) [6], a known polyketide-derived $\gamma$-lactone that was also isolated in this investigation, are closely related (ه Fig. 1). They were shown, however, to differ structurally only in the presence of an acetoxy functionality in $\mathbf{1}$ instead of a hydroxyl. This inference was in accordance with the downfield shifted signals of two diastereotopic oxymethylene hydrogens at $\delta 3.98(\mathrm{dd}, J=11.2$ and $6.3 \mathrm{~Hz}$ ) and $\delta 4.08(\mathrm{dd}, J=11.2$ and $3.7 \mathrm{~Hz}$ ) compared with those of $3\left(\delta_{\mathrm{H}} 3.59\right.$ and $\delta_{\mathrm{H}} 3.44$, assigned to $2 \mathrm{H}$ 3 '), as a result of the presence of an acetate group at C-3' in 1. Furthermore, long-range correlations discernible in the HMBC spectrum of 1 between the oxymethylene hydrogens $\mathrm{H}-\mathbf{3}^{\prime}$ and the acetoxy carbonyl at $\delta 171.1$ confirmed the location of this group at C$3^{\prime}$ as well as the coupling of these hydrogens to the oxymethine $\mathrm{H}$ $2^{\prime}$ at $\delta 3.80-3.91(\mathrm{~m})$ as revealed by the COSY spectrum. The positive value of the specific rotation of $1,[\alpha]_{\mathrm{D}}^{20}+20.86(c 0.12$, acetone), suggested that its absolute configuration is the same as that of 3, namely $\left(2 S, 4 R, 2^{\prime} R\right)$. Therefore, the structure of compound $\mathbf{1}$, which is being described for the first time, was unambiguously shown to be 3 '-acetylrubrenolide ( $\odot$ Fig. 1 ).

The IR, ${ }^{1} \mathrm{H}$, and ${ }^{13} \mathrm{C}$ NMR spectra of $\mathbf{2}$ ( $\bigcirc$ Table 1 ) showed a striking resemblance with those described for 1 , except for the downfield shifted resonance of $\mathrm{H}-2$ ', which was observed as a multiplet at $\delta$ 5.05-5.14 in the ${ }^{1} \mathrm{H}$ NMR spectrum of 2 , and the presence of an additional methyl singlet at $\delta 2.02$ attributable to an acetate function at $\mathrm{C}-2^{\prime}$, thus suggesting that $\mathbf{2}$ was the corresponding acetyl derivative of 1 ( Fig. 1). Likewise, in the ${ }^{13} \mathrm{C}$ NMR spectrum, the signals assignable to the acetoxyl group at C-2' were observed at $\delta 20.6$ and $\delta 170.5$. The ion at $\mathrm{m} / \mathrm{z} 405.22455[\mathrm{M}+$ $\mathrm{Na}]^{+}$in the positive HRESIMS of $\mathbf{2}$, consistent with the molecular formula $\mathrm{C}_{21} \mathrm{H}_{34} \mathrm{O}_{6}$, reinforced the foregoing proposal. In addition, long-range connectivities discernible in the HMBC spectrum of $\mathbf{2}$ from the hydrogen $\mathrm{H}-2^{\prime}$ on the acetate-bearing carbon $\left(\delta_{\mathrm{H}} 5.05-\right.$ 5.14 ) to the acetoxy carbonyl at $\delta 170.5$ provided further support for these assignments ( $\bullet$ Fig. 2 ). Therefore, the above data al- 


\begin{tabular}{|c|c|c|c|c|c|c|}
\hline \multirow[t]{2}{*}{ Position } & \multicolumn{2}{|l|}{$1^{\mathrm{b}}$} & \multicolumn{2}{|l|}{$2^{\mathrm{b}}$} & \multicolumn{2}{|l|}{$3^{c}$} \\
\hline & $\delta_{\mathrm{H}}$ mult. $(\mathrm{I}$ in $\mathrm{Hz})$ & $\delta_{c}$ & $\delta_{\mathrm{H}}$ mult. $(J$ in $\mathrm{Hz})$ & $\delta_{C}$ & $\delta_{\mathrm{H}}$ mult. $(U$ in $\mathrm{Hz})$ & $\delta_{C}$ \\
\hline 1 & - & 180.0 & - & 178.0 & - & 180.0 \\
\hline 2 & $2.82-2.95 m$ & 38.8 & $2.45-2.64 m$ & 37.7 & $2.83-2.94 m$ & 38.7 \\
\hline \multirow[t]{2}{*}{3} & $2.44-2.56 \mathrm{~m}$ & 35.7 & $2.45-2.64 m$ & 35.5 & $2.53 \mathrm{ddd}(12.3,8.4,5.4)$ & 35.7 \\
\hline & $1.42-1.61 \mathrm{~m}$ & & $1.40-1.57 \mathrm{~m}$ & & $1.54-1.62 \mathrm{~m}$ & \\
\hline 4 & $4.26-4.48 m$ & 79.7 & $4.25-4.36 \mathrm{~m}$ & 79.0 & $4.31-4.42 m$ & 79.9 \\
\hline \multirow[t]{2}{*}{5} & $1.63-1.77 \mathrm{~m}$ & 35.3 & $1.62-1.76 \mathrm{~m}$ & 35.3 & $1.71-1.81 \mathrm{~m}$ & 35.3 \\
\hline & $1.42-1.61 \mathrm{~m}$ & & $1.57-1.62 \mathrm{~m}$ & & $1.56-1.66 \mathrm{~m}$ & \\
\hline \multirow[t]{2}{*}{6} & $1.20-1.40$ brs & 25.1 & $1.31-1.49 \mathrm{~m}$ & 25.1 & $1.42-1.52 \mathrm{~m}$ & 25.2 \\
\hline & & & & & $1.32-1.42 \mathrm{~m}$ & \\
\hline 7 & $1.20-1.40$ brs & $29.2^{d}$ & $1.20-1.40 \mathrm{brs}$ & $29.2^{\mathrm{e}}$ & $1.25-1.40 \mathrm{brs}$ & $29.3^{f}$ \\
\hline 8 & $1.20-1.40$ brs & $28.0^{d}$ & $1.20-1.40 \mathrm{brs}$ & $29.0^{e}$ & $1.25-1.40 \mathrm{brs}$ & $29.0^{f}$ \\
\hline 9 & $1.20-1.40$ brs & $29.3^{d}$ & $1.20-1.40 \mathrm{brs}$ & $29.3^{e}$ & $1.25-1.40 \mathrm{brs}$ & $29.3^{f}$ \\
\hline 10 & $1.20-1.40 \mathrm{brs}$ & $28.8^{d}$ & $1.20-1.40 \mathrm{brs}$ & $28.8^{e}$ & $1.25-1.40 \mathrm{~m}$ & $28.8^{f}$ \\
\hline 11 & $1.20-1.40$ brs & $29.3^{d}$ & $1.20-1.40$ brs & $29.3^{e}$ & $1.25-1.40 \mathrm{brs}$ & $29.3^{f}$ \\
\hline 12 & $1.90-2.00 \mathrm{~m}$ & 33.7 & $1.95-2.00 \mathrm{~m}$ & 33.7 & $2.00 d d(14.0,6.6)$ & 33.7 \\
\hline 13 & $\begin{array}{l}5.76 d d t(16.8 \\
11.2,6.6)\end{array}$ & 139.1 & $5.76 d d t(16.8,11.2,6.6)$ & 139.1 & $5.75 d d t(16.8,11.2,6.6)$ & 139.1 \\
\hline \multirow[t]{2}{*}{14} & $4.95 b r d(16.8)$ & 114.1 & $4.95 b r d(16.8)$ & 114.1 & $4.95 \mathrm{brd}(16.8)$ & 114.1 \\
\hline & $4.89 \operatorname{brd}(11.2)$ & & $4.89 \mathrm{brd}(11.2)$ & & 4.89 brd (11.2) & \\
\hline \multirow[t]{2}{*}{$1^{\prime}$} & $1.90-2.00 \mathrm{~m}$ & 34.0 & $2.29 \operatorname{ddd}(14.1,10.8,3.6)$ & 32.0 & $1.90-2.00 \mathrm{~m}$ & 33.7 \\
\hline & $1.42-1.61 \mathrm{~m}$ & & $1.53-1.62 m$ & & $1.55-1.61 \mathrm{~m}$ & \\
\hline $2^{\prime}$ & $3.80-3.91 \mathrm{~m}$ & 68.2 & $5.05-5.14 m$ & 69.0 & $3.65-3.75 \mathrm{~m}$ & 70.2 \\
\hline \multirow[t]{2}{*}{$3^{\prime}$} & $4.08 d d(11.2,3.7)$ & 68.4 & $4.22 d d(12.0,3.6)$ & 64.9 & 3.59 brd (10.8) & 66.6 \\
\hline & $3.98 d d(11.2,6.3)$ & & $3.99 \mathrm{dd}(12.0,6.3)$ & & $3.44 d d(10.8,6.3)$ & \\
\hline $\mathrm{R}_{1}$ & - & - & $2.02 \mathrm{~s}$ & $\begin{array}{l}20.6 \\
170.5\end{array}$ & - & - \\
\hline $\mathrm{R}_{2}$ & $2.05 \mathrm{~s}$ & $\begin{array}{l}20.8 \\
171.1\end{array}$ & $2.05 \mathrm{~s}$ & $\begin{array}{l}20.9 \\
170.6\end{array}$ & - & - \\
\hline
\end{tabular}

Table $1{ }^{1} \mathrm{H}$ and ${ }^{13} \mathrm{C}$ NMR data for compounds $\mathbf{1 - 3}$ in $\mathrm{CDCl}_{3}{ }^{\mathrm{a}}$.

${ }^{a}$ Assignments were confirmed by DEPT, ${ }^{1} \mathrm{H}-{ }^{1} \mathrm{COSY}, \mathrm{HSQC}$, and HMBC experiments; ${ }^{\mathrm{b}}$ Recorded at $300.13 \mathrm{MHz}\left({ }^{1} \mathrm{H}\right)$ and $75.47 \mathrm{MHz}\left({ }^{13} \mathrm{C}\right)$; ' Recorded at $500.13 \mathrm{MHz}\left({ }^{1} \mathrm{H}\right)$ and $125.76 \mathrm{MHz}\left({ }^{13} \mathrm{C}\right)$; d, e, f Interchangeable values within column

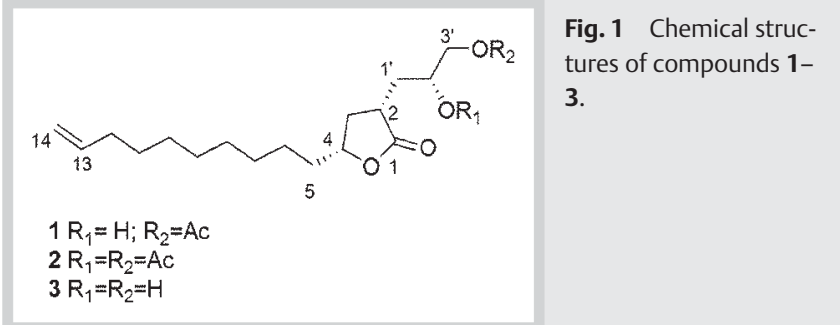

lowed compound 2 to be determined as 2',3'-diacetylrubrenolide, which is being reported for the first time as a natural product, yet it was formerly obtained by the acetylation of rubrenolide [6]. The ${ }^{1} \mathrm{H}$ and ${ }^{13} \mathrm{C}$ NMR spectral data of $\mathbf{2}$, not previously reported in the literature, are now presented in 0 Table $\mathbf{1 .}$

The molecular formula of 3 was established as $\mathrm{C}_{17} \mathrm{H}_{30} \mathrm{O}_{4}$ on the basis of its HRESIMS $\left(\mathrm{m} / \mathrm{z} 321.20350[\mathrm{M}+\mathrm{Na}]^{+}\right)$. Its ${ }^{1} \mathrm{H}$ and ${ }^{13} \mathrm{C}$ NMR spectral data ( Table 1 ) and specific rotation value agreed with those reported for rubrenolide, a butyrolactone that has been previously obtained from only one Lauraceae species, Nectandra rubra (Mez) C.K. Allen (synonym Sextonia rubra (Mez) van der Werff) [6,7], and also by stereoselective syntheses $[8,9]$ ( Fig. 1). The initially assigned $\left(2 S, 4 R, 2 S^{\prime}\right)$ configuration of rubrenolide was later shown to be $\left(2 S, 4 R, 2^{\prime} R\right)$ instead through its total synthesis [8]. Although the ${ }^{13} \mathrm{C}$ NMR data of 3 agreed with those published for rubrenolide [6], information provided by the HMBC spectrum of the former revealed that the previously reported resonance values due to $\mathrm{C}-4\left(\delta\right.$ 70.2) and $\mathrm{C}-2^{\prime}(\delta 79.7)$ should be interchanged. This assumption was substantiated by long-range correlations observed from $\mathrm{H}-3$ and $\mathrm{H}-5$ to $\mathrm{C}-4$, and from $\mathrm{H}-1^{\prime}$ and $\mathrm{H}-3^{\prime}$ to $\mathrm{C}-2^{\prime}$ in the $\mathrm{HMBC}$ spectrum of 3 ( Fig. 2), thus allowing unambiguous assignments of C-4 and C-2' resonances as $\delta 79.9$ and $\delta 70.2$, respectively.

Following isolation, compounds 1-3 were further assessed for their in vitro antiproliferative effects against six cancer cell lines using the SRB assay. As depicted in Table 2, rubrenolide (3) was shown to be the most active butanolide, on the basis of its significant $\mathrm{GI}_{50}$ values in the range of 3.3 and $9.9 \mu \mathrm{g} / \mathrm{mL}$ against four of the six cell lines tested (UACC-62, MCF-7, HT-29, and PC-3), while $\mathbf{1}$ and $\mathbf{2}$ showed moderate antiproliferative effects.

\section{Material and Methods}

$\nabla$

Plant material: The leaves of $M$. crassiramea were collected in Campo Grande, MS, Brazil, in July 2011. A voucher specimen (No.33014) was deposited at the CGMS Herbarium of the Univesidade Federal de Mato Grosso do Sul.

Extraction and isolation: Air-dried and powdered leaves (1.96 kg) of $M$. crassiramea were extracted with EtOH (20 L) at room temperature. Partitioning of the EtOH extract gave the hexane, $\mathrm{CH}_{2} \mathrm{Cl}_{2}$, and EtOAc phases with the brine shrimp toxicity residing in the $\mathrm{CH}_{2} \mathrm{Cl}_{2}$ solubles. Repeated CC procedures on silica gel and Sephadex $\mathrm{LH}-20$ of the bioactive $\mathrm{CH}_{2} \mathrm{Cl}_{2}$ phase afforded compounds 1-3. The detailed extraction and isolation procedures of 1-3 are available as Supporting Information.

Brine shrimp lethality and in vitro cytotoxic assays: The brine shrimp (A. salina) lethality test was performed with extracts and phases according to Meyer et al. [10]. Cytotoxicity of compounds 1-3 was measured in vitro by growth inhibition of six human 


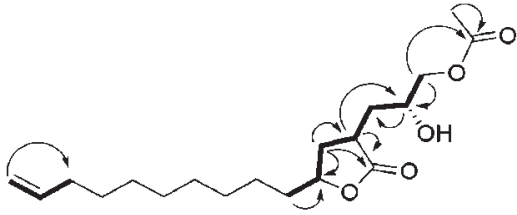

1

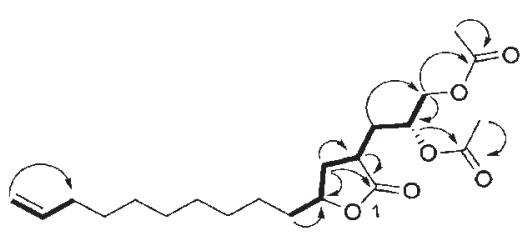

2

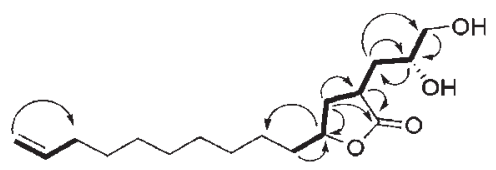

3

Fig. 2 Key HMBC $(\rightarrow)$ and ${ }^{1} \mathrm{H}^{-1} \mathrm{H} \operatorname{COSY}(-)$ correlations of 1-3.

Table 2 Antiproliferative effects of compounds 1-3 on human cancer cell lines $\left(\mathrm{GI}_{50}, \mu \mathrm{g} / \mathrm{mL}\right)$.

\begin{tabular}{lllrl} 
Cell lines & $\mathbf{1}$ & $\mathbf{2}$ & \multicolumn{1}{l}{ 政 } & Doxorubicin \\
\hline PC-3 & $21.2 \pm 1.2$ & $19.1 \pm 1.4$ & $9.9 \pm 2.0$ & $0.2 \pm 0.1$ \\
\hline $786-0$ & $31.5 \pm 0.2$ & $16.5 \pm 0.5$ & $18.8 \pm 1.0$ & $0.7 \pm 0.1$ \\
\hline HT-29 & $29.5 \pm 0.1$ & $30.7 \pm 0.3$ & $5.1 \pm 2.0$ & $0.3 \pm 0.1$ \\
\hline MCF-7 & $26.4 \pm 1.9$ & $17.1 \pm 2.2$ & $3.7 \pm 0.8$ & $0.1 \pm 0.1$ \\
UACC-62 & $46.5 \pm 4.3$ & $>250.0$ & $3.3 \pm 1.0$ & $0.3 \pm 0.1$ \\
\hline NCI/ADR-RES & $21.5 \pm 2.5$ & $23.5 \pm 0.2$ & $22.6 \pm 2.1$ & $3.0 \pm 0.4$
\end{tabular}

cancer cell lines - namely, 786-0 (kidney carcinoma), MCF-7 (breast adenocarcinoma), PC-3 (prostate carcinoma), HT-29 (colon adenocarcinoma), UACC-62 (melanoma), and NCI/ADR-RES (ovarian multidrug-resistant) using the SRB assay, as described elsewhere $[11,12]$. The detailed experimental procedures are available as Supporting Information.

\section{Supporting information}

The detailed extraction and isolation data of compounds $\mathbf{1 - 3}$, as well as their ${ }^{1} \mathrm{H}$ and ${ }^{13} \mathrm{C}$ 1D- and 2D-NMR, IR, and HR-ESIMS spectra, specific optical rotation values, and bioassays procedures are available as Supporting Information.

\section{Acknowledgements}

$\nabla$

The authors are grateful to FUNDECT-MS and PROPP-UFMS for their financial support and to CAPES and CNPQ for the grants awarded. Dr. Flávio M. Alves (CGMS Herbarium, Universidade Federal de Mato Grosso do Sul) is acknowledged for his assistance in the identification of the plant material. Dr. Norberto P. Lopes and Dr. Gil Valdo J. da Silva (Faculdade de Ciências Farmacêuticas, USP) are acknowledged for the HR-ESIMS measurements and the 2D-NMR spectra (500/125 MHz) of compounds 2 and 3, respectively. Thanks are also given to Dr. João E. de Carvalho (CPQBA, UNICAMP) for providing the cancer cell lines.

\section{Conflict of Interest \\ $\nabla$}

The authors declare no conflicts of interest.

\section{References}

1 Alves FM, Souza VC. Two new species of Mezilaurus (Lauraceae) from Brazil. Brittonia 2012; 64: 257-262

2 van der Werff H. A revision of Mezilaurus (Lauraceae). Ann Missouri Bot Gard 1987; 74: 153-182
3 Alcântara JM, Yamaguchi KKL, Veiga-Junior VF. Composição de óleos essenciais de Dicypellium manausense, Mezilaurus duckei, Mezilaurus itauba e Pleurothyrium vasquezii, quatro espécies amazônicas da família Lauraceae. B Latinoam Caribe Pl 2013; 12: 469-475

4 Yanez XR, de Diaz AMP, Diaz DPP. Neolignans from Mezilaurus itauba. Phytochemistry 1986; 25: 1953-1956

5 Silva R, Nagem TJ, Mesquita AAL, Gottlieb OR. $\gamma$-Lactones from Mezilaurus synandra. Phytochemistry 1983; 22: 772-773

6 Franca NC, Gottlieb OR, Coxon DT. Rubrenolide and rubrynolide: an alkene-alkyne pair from Nectandra rubra. Phytochemistry 1977; 16: 257-262

7 Rodrigues AMS, Theodoro PNET, Eparvier V, Basset C, Silva MRR, Beauchêne J, Espíndola LS, Stien D. Search for antifungal compounds from the wood of durable tropical trees. J Nat Prod 2010; 73: 1706-1707

8 Thijs L, Zwanenburg B. Rubrenolide, total synthesis and revision of its reported stereochemical structure. Tetrahedron 2004; 60: 5237-5252

9 Madda J, Khandregula S, Bandari SK, Kommu N, Yadav JS. Stereoselective total synthesis of rubrenolide and rubrynolide. Tetrahedron Asymmetr 2014; 25: 1494-1500

10 Meyer BN, Ferrigni NR, Putnam JE, Jacobsen LB, Nichols DE, McLaughlin $J L$. Brine shrimp: a convenient general bioassay for active-plant constituents. Planta Med 1982; 45: 31-34

11 Skehan P, Storeng R, Scudiero D, Monks A, McMahon J, Vistica D, Warren $J T$, Bokesch H, Kenney S, Boyd MR. New colorimetric cytotoxicity assay for anticancer-drug screening. J Natl Cancer Inst 1990; 82: 1107-1112

12 Monks A, Scudiero D, Skehan P, Shoemaker R, Paull K, Vistica D, Hose C, Langley J, Cronise P, Vaigro-Wolff A, Gray-Goodrich M, Campbell H, Mayo $J$, Boyd M. Feasibility of a high-flux anticancer drug screen using a diverse panel of cultured human tumor cell lines. J Natl Cancer Inst 1991; 83: 757-766

received August 14, 2015

revised August 14, 2015

accepted January 15, 2016

\section{Bibliography}

DOI http://dx.doi.org/10.1055/s-0035-1568355

Published online February 11, 2016

Planta Med Lett 2016; 3: e14-e16

(c) Georg Thieme Verlag KG Stuttgart · New York .

ISSN 2199-157X

\section{Correspondence}

\section{Dr. Fernanda Rodrigues Garcez}

Universidade Federal de Mato Grosso do Sul

Instituto de Química

Avenida Senador Filinto Muller 1555

79074-460 Campo Grande, MS

Brazil

Phone: + 556733453579

fernandargarcez@gmail.com 